\title{
Evaluation of the Temporary Tent Cover Truss System, AP Primary Vent System
}

\author{
M. A. Haq \\ Washington River Protection Solutions LLC \\ Richland, WA 99352 \\ U.S. Department of Energy Contract DE-AC27-08RV14800

$\begin{array}{llll}\text { EDT/ECN: } & 823438 & \text { UC: N/A } & \\ \text { Cost Center: } & 7 \mathrm{G} 110 & \text { Charge Code: } & 200065 \\ \text { B\&R Code: } & \text { N/A } & \text { Total Pages: } & 26\end{array}$

Key Words: AP tank farms, Central Exhaust Station Enclosure, Tent Cover, Tubular Truss System

Abstract: The purpose of this calculation is to evaluate a temporary tent cover truss system. This system will be used to provide weather protection to the workers during replacement of the filter for the Primary Ventilation System in AP Tank Farm. The truss system has been fabricated utilizing tubes and couplers, which are normally used for scaffoldings.

TRADEMARK DISCLAIMER. Reference herein to any specific commercial product, process, or service by trade name, trademark, manufacturer, or otherwise, does not necessarily constitute or imply its endorsement, recommendation, or favoring by the United States Government or any agency thereof or its contractors or subcontractors.

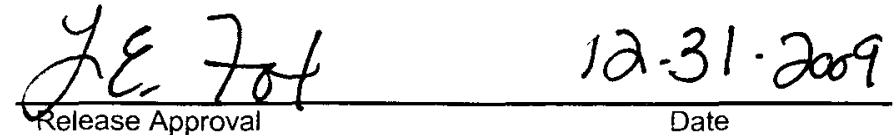

Approved For Public Release

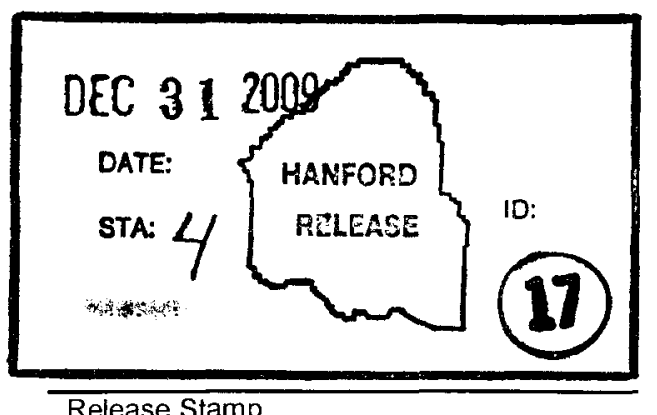

Release Stamp 


\section{Calculation Review Checklist.}

Calculation Reviewed: RPP-CALC-44193 R0

Scope of Review: Entire Calculations

(e.g., document section or portion of calculation)

Engineer/Analyst: M. A. Haq maingt al

Date: $12 / 30 / 09$

Organizational Manager: M. A. Roberts Whe $12 / 30 / 2008$

This document consists of 10 pages and the following attachments (if applicable):

ATTACH. A: Photos of Tent Cover Truss System

ATTACH B: Sketch for the Tent Cover truss System

ATTACH C: Field Sketch for Typical Tent Cover Truss

ATTACH D: Density of Snow Cover Info.l

ATTACH E: Alternate Calc. to veify the Strl Integrity of the Truss System during Hoisting \&

Rigging

Yes No $\mathrm{NA}^{*}$

[X] [ ] [ ] 1. Analytical and technical approaches and results are reasonable and appropriate.

[x] [ ] [ ] 2. Necessary assumptions are reasonable, explicitly stated, and supported.

[x ] [ ] [] 3. Ensure calculations that use software include a paper printout, microfiche, CD-ROM, or other electronic file of the input data and identification to the computer codes and versions used, or provide alternate documentation to uniquely and clearly identify the exact coding and execution process.

[x] [ ] [ ] 4. Input data were checked for consistency with original source information.

[x] [ ] [ ] 5. Key input data (e.g., dimensions, performance characteristics) that may affect equipment design is identified.

[x] [ ] [ ] 6. For both qualitative and quantitative data, uncertainties are recognized and discussed and the data is presented in a manner to minimize design interpretations.

[x] [ ] [ ] 7. Mathematical derivations were checked, including dimensional consistency of results.

[x] [ ] [ ] 8. Calculations are sufficiently detailed such that a technically qualified person can understand the analysis without requiring outside information.

[x ] [ ] [] 9. Software verification and validation are addressed adequately.

[x] [ ] [ ] 10. Limits/criteria/guidelines applied to the analysis results are appropriate and referenced. Limits/criteria/guidelines were checked against references.

[x] [ ] [ ] 11. Conclusions are consistent with analytical results and applicable limits.

[x] [ ] [ ] 12. Results and conclusions address all points in the purpose.

[x] [] [] 13. Referenced documents are retrievable or otherwise available.

[x] [ ] [ ] 14. The version or revision of each reference is cited.

[x] [ ] [ ] 15. The document was prepared in accordance with Attachment A, "Calculation Format and Preparation Instructions."

[] [ ] [x ] 16. Impacts on requirements have been assessed and change documentation initiated to incorporate revisions to affected documents, as appropriate.

[x] [] [ ] 17. All checker comments have been dispositioned and the design medja matches the calculations. or notetion has been a fdecl.

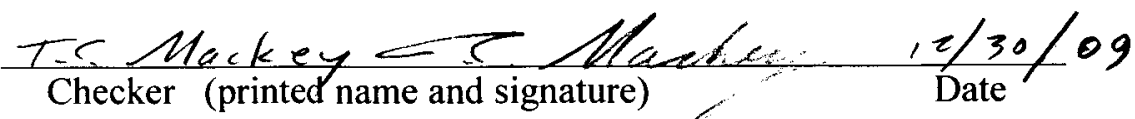

* If No or NA is chosen, an explanation must be provided on or attached to this form.

Item 16: No impact to requirements and no change documentation is required. 
Subject: Evaluation of the Temporary Tent Cover Truss System, AP Primary Vent. System $\begin{array}{ll}\text { Originator: } \text { M. A. Haq Mriantal } & \text { Date: } 12 / 22 / 09 \\ \text { Checker: TC Mackey } & \text { Date: } 12 / 30 / 09\end{array}$

Organizational Mgr..M A. Roberts/m? Rolvo Date: $12 / 30 / 2009$

\subsection{Objective/Purpose:}

The purpose of this calculation is to evaluate the tent cover truss system (see Atttach. A for the photos of this sytstem). This system will be used to provide weather protection to the workers during replacement of the filter for the Primary Ventilation System in AP Tank Farm. The truss system has been fabricated utilizing tubes and couplers, which are normally used for scaffoldings. This system, presently located near the Primary Ventilation System, consists of 23 feet wide wide trusses, with their bottom chord members extending 26 feet wide, and is 36 feet long (see Attach. B for the field dimensions of the typical truss). This truss system will be lifted from the ground, and placed on top of the concrete walls of Central Exhaust Station Enclosure (see drawings $\mathrm{H}-2-90456$, and H-2-90457, Sh 1 for the enclosure), as a temporary roof structure. The shorter side of the truss system, 23 feet wide, will be sitting on the east-west concrete walls (see Plan, dwg H-2-90456 for concrete walls, located with dimension of 23'-3", outer face of east wall to outer face of west wall). The truss system will overhang approximately 8 ' $-(9-1 / 2)$ " beyond the south wall. The overhang portion of the truss system will be supported on two posts. The arrangement of the truss support system has been shown in Attach.B. Once installed, the truss system will be covered with tarp, for weather protection.

\subsection{Results/Conclusions:}

This is a temp tent. RPP-7933 only requires $55 \mathrm{mph}$. Conc, block sizEsare only recommendel The truss support assembly meets the requirements for natural phenomena hazards loads in aceordance with TFG-ENG-STD-06 (Ref.3) for.PC 1 structure. However, the temporary truss system is restricted for snow loading (up to $3 / 8$ " thick fresh snow). The truss system has to be cleared off snow, if snow exceeds more than $3 / 8 "$ ". The tarp, covering the truss system, has not been evaluated for wear and tear due to snow or ice loadings.

No seismic analysis has been performed, since this is a temporary structure. Moreover, based on engineering judgement, it is expected that wind loading will govern.

Alternate calculations have been done to check the integrity of the truss system framing (see Attach E). Add clamps over the horizontal member couplings (where the tubular members are connected to each other). The truss system can be lifted by using the following two options:

a. Use four pick points on east and west sides of the truss system.

b. In case two interior pick points are used for lifting, add bracings (as shown on the Sketch on pg E-3). Double clamp the added bracings or use double bracings.

3.0 Input Data:

a. Dimensions of the truss system were obtained from the field (See Attach. C). The components of the truss system consist of 2" diameter tubes, and couplerss, normally used by Safway Scaffoldings.

b. Tent Cover Truss System weight is $3100 \mathrm{lbs}$. This weight was taken in the field by lifting the truss system from the ground, using a dynamometer. If proposed bracings, as shown on the Sketch on pg. E-3 are added, it will add approximately $400 \mathrm{lbs}$ to the truss system.

c. The truss system assembly has been analyzed as PC-1 per TFC-ENG-STD-06 (Ref. 3).

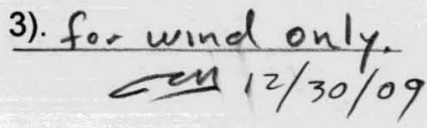


Subject: Evaluation of the Temporary Tent Cover Truss System, AP Primary Vent. System

Originator: M.A. Haq mamatay

Date: $12 / 22 / 09$

Checker: TC Mackey Date: $/ 2 / 30 / 09$

Organizational Mgr.M A. Roberts $M$ an fuse Date: : $2 / 30 / 2009$

\subsection{Assumptions:}

None

\subsection{Method of Analysis}

Manual calculations are used for this analysis using MathCAD. The truss system is analyzed for wind loading per ASCE 7-05 (Ref. 1)

\section{Design Wind Force}

The wind loads are determined from ASCE 7-05 (Ref. 1) Method 1, Simplified Procedure. $V=85 \mathrm{mph}$ ( Table 3, Ref. 3)

\section{Evaluation of the Truss System}

\section{a). Evaluation of the Truss System Portion Positioned on the Concrete Walls}

Slope of the roof truss (based on $\tan =4^{\prime}-0^{\prime \prime} / 11^{\prime}-6^{\prime \prime}$ from Attach. $B$ ) $=18.8$ degrees

Using Fig. 6-2, pg 37 (Ref. 1), the maximum wind force in the longitudinal direction for a wind velocity of $85 \mathrm{mph}$, with angle roof of 20 degrees, Zone $\mathrm{E}$ (vertical pressure) is $13.8 \mathrm{psf}$. Note: Fig. 6.2 is based on a structure height of 30 feet, however the adjustment factor $\lambda$ for this height, according to table on pg 40 of Ref. 1 is 1 .

$$
\begin{aligned}
& \mathrm{w}_{1}:=13.8 \cdot \mathrm{psf} \\
& \mathrm{L}_{1}:=27 \cdot \mathrm{ft} \\
& \mathrm{L}_{2}:=36 \cdot \mathrm{ft} \\
& \mathrm{w}_{1}:=23 \cdot \mathrm{ft} \\
& \mathrm{U}_{1}:=\mathrm{w}_{1} \cdot \mathrm{L}_{1} \cdot \mathrm{w}_{1} \\
& \mathrm{U}_{1}=8.57 \times 10^{3} \mathrm{lbf} \\
& \mathrm{w}_{\text {truss }}:=3100 \cdot \mathrm{lbf} \\
& \mathrm{w}_{\text {truss } 1}:=\mathrm{w}_{\text {truss }} \cdot \frac{\mathrm{L}_{1}}{\mathrm{~L}_{2}} \\
& \mathrm{w}_{\text {truss } 1}=2.325 \times 10^{3} \mathrm{lbf} \\
& \mathrm{U}_{\text {net } 1}:=\mathrm{U}_{1}-\mathrm{w}_{\text {truss } 1} \\
& \mathrm{U}_{\text {net } 1}=6.245 \times 10^{3} \mathrm{lbf}
\end{aligned}
$$

\author{
Uplift pressure on the truss system \\ Length of truss system \\ Total length of the truss system
}

Width of the truss system

Total uplift force on the truss system

Total weight of the truss system.

Weight of truss system, positioned on the concrete walls. Note: 27 feet length of truss system is being supported on concrete walls

Net uplift on the truss system (positioned on the concrete walls) 
Subject: Evaluation of the Temporary Tent Cover Truss System, AP Primary Vent. System Originator: M. A. Haq Checker: TC Mackey Date: $12 / 22 / 09$ Organizational Mgr.M A. Roberts $T_{2} z_{2}$ Keger Date: $12 / 30 / 09$

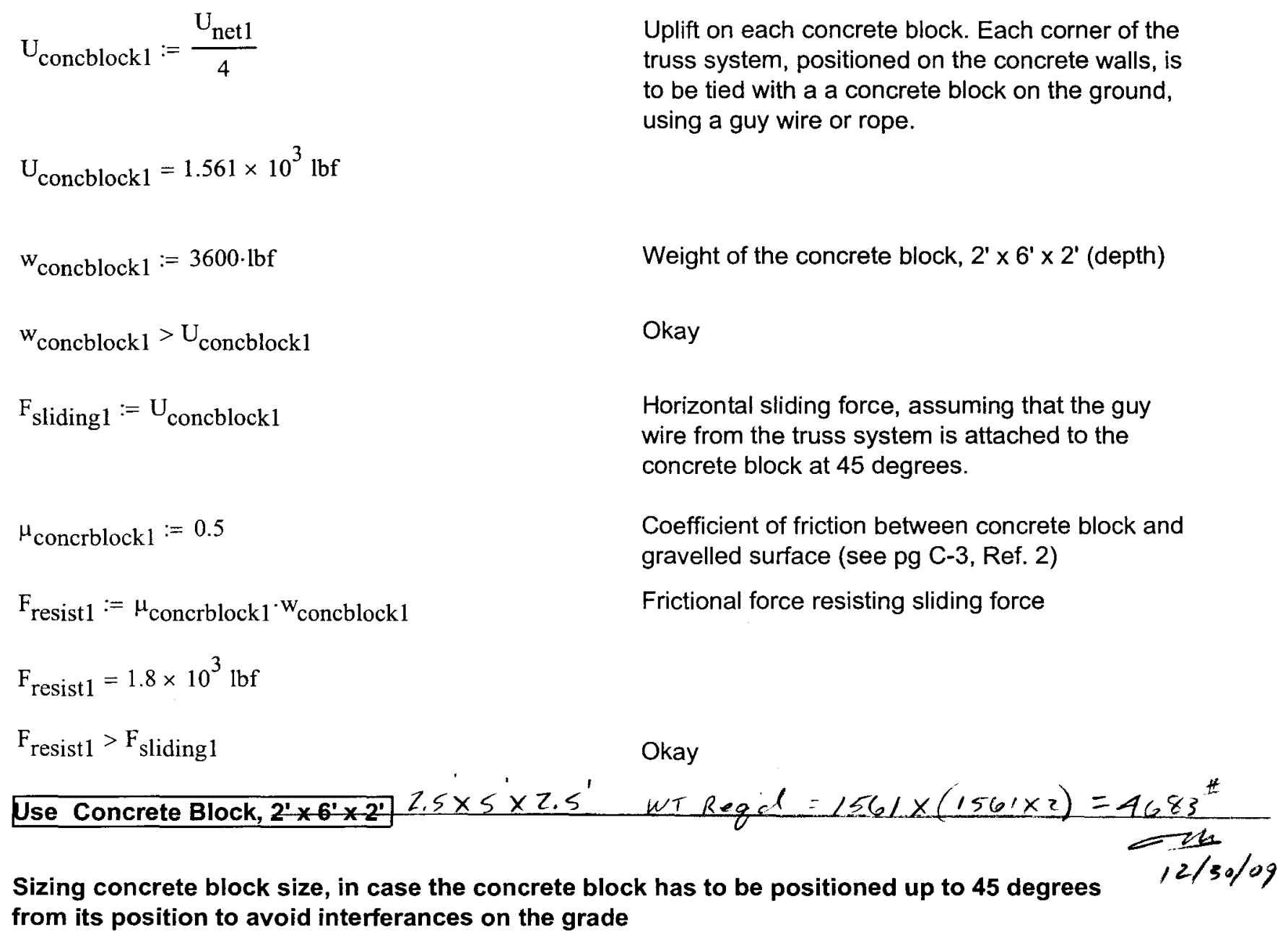

Uplift on each concrete block. Each corner of the truss system, positioned on the concrete walls, is to be tied with a concrete block on the ground, using a guy wire or rope.

Weight of the concrete block, $2^{\prime} \times 6^{\prime} \times 2^{\prime}$ (depth)

Okay

Horizontal sliding force, assuming that the guy wire from the truss system is attached to the concrete block at 45 degrees.

Coefficient of friction between concrete block and gravelled surface (see pg C-3, Ref. 2)

Frictional force resisting sliding force

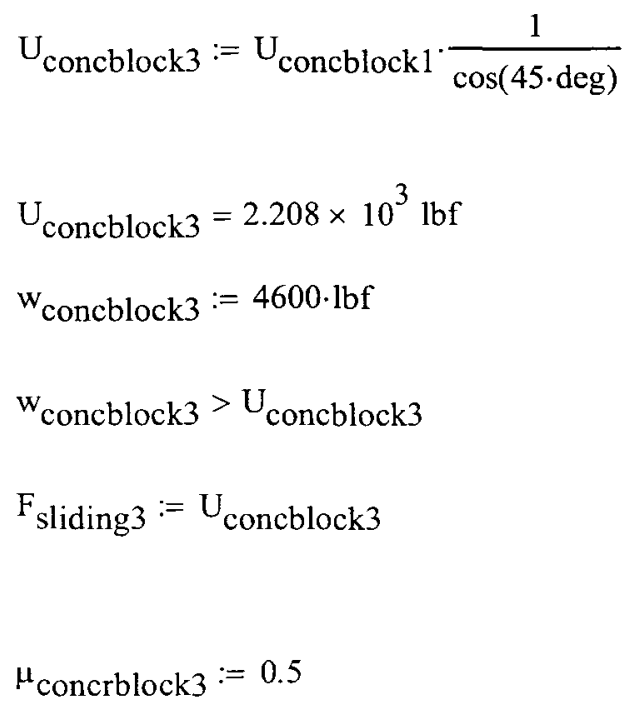


Subject: Evaluation of the Temporary Tent Cover Truss System, AP Primary Vent. System Originator: M. A. Hag Checker: TC Mackey miamstat Date: $12 / 22 / 09$ Organizational Mgr.M A. Roberts Date: $12 / 30 / 09$

$$
\begin{array}{ll}
\mathrm{F}_{\text {resist } 3}:=\mu_{\text {concrblock } 3} \cdot \mathrm{w}_{\text {concblock} 3} & \text { Frictional force resisting sliding force } \\
\mathrm{F}_{\text {resist } 3}=2.3 \times 10^{3} \mathrm{lbf} & \\
\mathrm{F}_{\text {resist3 }}>\mathrm{F}_{\text {sliding } 1} & \text { Okay }
\end{array}
$$

\section{Use Concrete Block, 2.5' $\times 5^{\prime} \times 2.5$, in case the concrete block has to be rotated up to 45 degrees (in the plan) to miss interferances on the grade (see Sketch on pg B-2 for conc. blocks, $4600 \mathrm{lbs}$ ).}

\section{Check Size of Guy Wire}

Guy wire or rope will be attached from each corner of the truss system (positioned on the walls) to the concrete blocks as shown in Attach. B.

$$
\begin{array}{ll}
\mathrm{P}_{\text {wire }}:=\frac{\mathrm{U}_{\text {concblock } 3}}{\sin (45 \cdot \mathrm{deg})} & \text { Tension } \\
\mathrm{P}_{\text {wire }}=3.122 \times 10^{3} \mathrm{lbf} & \\
\mathrm{P}_{\text {capacity }}:=10.7 \cdot 2 \cdot \mathrm{kip} & \begin{array}{l}
\text { Tensile } \\
\text { Rope }
\end{array} \\
\text { FOS }_{\text {wire }}:=\frac{\mathrm{P}_{\text {capacity }}}{\mathrm{P}_{\text {wire }}} & \\
\text { FOS }_{\text {wire }}=6.854 & \text { Okay }
\end{array}
$$

Tension force on the wire

$$
\text { Tensile capacity of 1/2" } \phi, 6 \times 19 \text { Fiber Core Wire }
$$
Rope (See pg A-13, Ref.2)

\section{Use 1/2" $\phi, 6 \times 19$ Fiber Core Wire Rope or equivalent wire rope, with a minimum breaking} strength or capacity of 10 kips

\section{b. Evaluation of the Truss System portion, positioned on the Posts}

Using figure 6-2, pg 37 (Ref. 1), the maximum wind force in longitudinal direction for wind velocity of $85 \mathrm{mph}$, with angle roof 20 degrees, Zone $\mathrm{E}$ (vertical pressure) is $13.8 \mathrm{psf}$.

$$
\begin{array}{ll}
\mathrm{WhW}_{\mathrm{W}}:=13.8 \cdot \mathrm{psf} & \text { Uplift force on the truss system } \\
\mathrm{L}_{3}:=9 \cdot \mathrm{ft} & \text { Length of truss system } \\
\mathrm{L}_{2}:=36 \cdot \mathrm{ft} & \text { Total length of the truss system }
\end{array}
$$

$\mathrm{W}_{\mathrm{m}}:=23 \cdot \mathrm{ft}$

Width of the truss system 
Subject: Evaluation of the Temporary Tent Cover Truss System, AP Primary Vent. System

Originator: M. A. Haq

miantat

Date: $12 / 22 / 09$

Checker: TC Mackey

Organizational Mgr.M A. Roberts $/$ mut

Date: $12 / 30 / 09$

$$
\begin{aligned}
& \mathrm{U}_{2}:=\mathrm{w}_{1} \cdot \mathrm{L}_{3} \cdot \mathrm{w}_{1} \\
& \mathrm{U}_{2}=2.857 \times 10^{3} \mathrm{lbf} \\
& \mathrm{w}_{\text {truss } 2}:=\mathrm{w}_{\text {truss }} \cdot \frac{\mathrm{L}_{3}}{\mathrm{~L}_{2}} \\
& \mathrm{w}_{\text {truss } 2}=775 \mathrm{lbf} \\
& \mathrm{U}_{\text {net2 }}:=\mathrm{U}_{2}-\mathrm{w}_{\text {truss } 2} \\
& \mathrm{U}_{\text {net2 }}=2.082 \times 10^{3} \mathrm{lbf} \\
& \mathrm{U}_{\text {concblock2 }}:=\frac{\mathrm{U}_{\text {net2 }}}{4}
\end{aligned}
$$$$
\mathrm{U}_{\text {concblock2 }}=520.4 \mathrm{lbf}
$$$$
\mathrm{w}_{\text {concblock } 2}:=1350 \cdot \mathrm{lbf}
$$$$
\mathrm{w}_{\text {concblock2 }}>\mathrm{U}_{\text {concblock2 }}
$$$$
\mathrm{F}_{\text {sliding2 }}:=\mathrm{U}_{\text {concblock2 }}
$$

Total uplift force on the truss system

Date: $/ 2 / 30 / 2002$

Total weight of the truss system.

Weight of truss system, supported by the posts. Note: 9 feet length of truss system is being supported by the two posts

Net uplift on the truss system (supported on the posts)

Uplift on each concrete block. Each corner of the truss system, positioned on the concrete walls, is to be tied with a concrete block on the ground, using a guy wire or rope.

Weight of the concrete block, $3^{\prime} \times 3^{\prime} \times 1$ (depth)'

Okay

Horizontal sliding force, assuming that the guy wire from the truss system is attached to the concrete block at 45 degrees.

Coefficient of friction between concrete block and gravelled surface (see pg C-3, Ref.)

Frictional force resisting sliding force

$$
\begin{aligned}
& \mathrm{F}_{\text {resist } 2}=675 \mathrm{lbf} \\
& \mathrm{F}_{\text {resist } 2}>\mathrm{F}_{\text {sliding2 }}
\end{aligned}
$$

$\frac{1350^{\#}}{U s e \text { Concrete Block, 3' } \times 3^{\prime} \times 1}+200^{\#}$

Okay

$w T \cdot$ Reg'd $=520+(520 \times 2)=1560^{\#}$

\section{Check Post for supporting the Truss System (see Attach B)}


Subject: Evaluation of the Temporary Tent Cover Truss System, AP Primary Vent. System

Originator: M. A. Haq mia. $A f a q$
Checker: $T$ C Mackey

Date: $12 / 22 / 09$

Organizational Mgr.M A. Roberts $/ M_{m} L_{2}$ Ke _ Date: $12 / 30 / 09$

Try tubular size 2" $\phi$ (normally used by Safway Scaffolding)

Properties of tubular post 2" $\phi$ (See pg A-12, Ref. 2):

$$
\begin{array}{ll}
\mathrm{A}_{\text {post }}:=0.75 \cdot \mathrm{in}^{2} & \text { Area of the post } \\
\mathrm{I}_{\text {post }}:=0.29 \cdot \mathrm{in}^{4} & \text { Moment of inertia of the post } \\
\mathrm{S}_{\text {post }}:=.310 \cdot \mathrm{in}^{3} & \text { Section modulus of the post } \\
\mathrm{r}_{\text {post }}:=\sqrt{\frac{\mathrm{I}_{\text {post }}}{\mathrm{A}_{\text {post }}}} & \text { Radius of gyration of the post } \\
\mathrm{r}_{\text {post }}=0.622 \text { in } & \text { Height of the post } \\
\mathrm{L}_{\text {post }}:=8 \cdot \mathrm{ft}+3 \cdot \text { in } & \\
\mathrm{K}_{\text {post }}:=1 & \text { Effective length factor of post, pg 3-5, Ref. } 4 \\
\mathrm{~F}_{\mathrm{y}}:=36 \cdot \mathrm{ksi} & \text { Yield stress of steel } \\
\mathrm{E}:=29 \cdot 10^{3} \cdot \mathrm{ksi} & \text { Elastic modulus of steel } \\
\mathrm{C}_{\mathrm{c}}:=\sqrt{\frac{\mathrm{K}_{\text {post }}}{\mathrm{L}_{\text {post }}}} & \\
\mathrm{K}_{\text {post }} &
\end{array}
$$


Subject: Evaluation of the Temporary Tent Cover Truss System, AP Primary Vent. System

Originator: M. A. Haq manAfaq

Date: $12 / 22 / 09$

Date: $12 / 30 / 09$

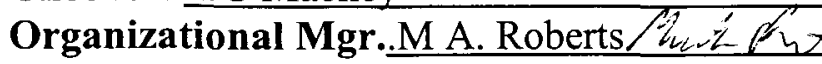

$$
\begin{aligned}
& \frac{\mathrm{K}_{\text {post }} \cdot \mathrm{L}_{\text {post }}}{\mathrm{r}_{\text {post }}}>\mathrm{C}_{\mathrm{c}} \\
& \mathrm{F}_{\mathrm{a}}:=\frac{12 \cdot \pi^{2} \cdot \mathrm{E}}{23 \cdot\left(\frac{\mathrm{K}_{\text {post }} \cdot \mathrm{L}_{\text {post }}}{\mathrm{r}_{\text {post }}}\right)^{2}} \\
& \mathrm{~F}_{\mathrm{a}}=5.891 \times 10^{3} \text { psi }
\end{aligned}
$$

Allowable Axial Stress per Eq E2-2, pg 5-42, Ref. 4

\section{Load on the post}

$$
\begin{aligned}
& \mathrm{w}_{\text {tarp }}:=500 \cdot \mathrm{lbf} \\
& \mathrm{w}:=\mathrm{w}_{\text {truss }}+\mathrm{w}_{\text {tarp }} \\
& \mathrm{P}_{\text {deadload }}:=\left(\mathrm{w} \cdot \frac{\mathrm{L}_{3}}{\mathrm{~L}_{1}} \cdot \frac{1}{2}\right) \cdot \frac{1}{2} \\
& \mathrm{P}_{\text {deadload }}=300 \mathrm{lbf} \\
& \mathrm{W}_{\text {snow }}:=20 \cdot \mathrm{psf} \\
& \mathrm{P}_{\text {snow }}:=\left(\frac{\mathrm{W}_{\text {snow }} \cdot \mathrm{L}_{3} \cdot \mathrm{W}_{1}}{2}\right) \cdot \frac{1}{2} \\
& \mathrm{P}_{\text {post }}:=\mathrm{P}_{\text {deadload }}+\mathrm{P}_{\text {snow }} \\
& \mathrm{P}_{\text {post }}=1.335 \times 10^{3} \mathrm{lbf} \\
& \mathrm{f}_{\mathrm{a}}=1.78 \times 10^{3} \text { psi } \\
& \mathrm{F}_{\mathrm{a}}>\mathrm{f}_{\mathrm{a}}:=\frac{\mathrm{P}_{\text {post }}}{\mathrm{A}_{\text {post }}}
\end{aligned}
$$$$
\text { Assume weight of the tarp on truss }
$$$$
\text { Weight of truss }
$$$$
\text { Total weight of the truss system }
$$$$
\text { Dead load on the post }
$$$$
\text { Snow load, Sect. 3.5.2, Ref. } 3
$$

Snow load on the post

Total load on the post

Axial Stress on the post

Use Tubular or Pipe with 2" $\phi$ 
Subject: Evaluation of the Temporary Tent Cover Truss System, AP Primary Vent. System

Originator: M. A. Haq mramAfaq

Date: $12 / 22 / 09$ Date: $12 / 30 / 09$

Organizational Mgr.M A. Roberts Mhe Kato Date:12/30/zan

\section{Evaluation of the Typical Truss for Snow Loading}

There are 10 trusses in the truss system, spaced at 4 feet $c / c$, as shown on the sketch on pg. B-2

$$
\begin{aligned}
& \mathrm{w}_{\text {truss } 3}:=\frac{\mathrm{w}}{9} \\
& \mathrm{R}_{\text {truss }}:=\frac{\mathrm{w}_{\text {truss } 3}}{2} \\
& \mathrm{R}_{\text {truss }}=200 \mathrm{lbf} \\
& \mathrm{w}_{1}=23 \mathrm{ft} \\
& \mathrm{h}_{1}:=4 \cdot \mathrm{ft} \\
& \mathrm{S}_{\text {truss }}:=\left(\frac{\mathrm{h}_{1}}{\frac{\mathrm{w}_{1}}{2}}\right) \\
& \mathrm{S}_{\text {truss }}=0.348 \\
& \theta_{\text {truss }}:=19.2 \\
& \mathrm{~F}_{\text {top.chord }}:=\frac{\mathrm{R}_{\text {truss }}}{\sin \left(\theta_{\text {truss }} \cdot \operatorname{deg}\right)} \\
& F_{\text {top.chord }}=608.149 \mathrm{lbf} \\
& F_{\text {bot.chord }}:=F_{\text {top.chord }} \cdot \cos \left(\theta_{\text {truss }} \cdot \operatorname{deg}\right) \\
& \text { Force in the bottom chord } \\
& \mathrm{F}_{\text {bot.chord }}=574.322 \mathrm{lbf}
\end{aligned}
$$

The bottom chords of trusses, made of 2" diameter Safway tubular members is clamped with typical Safway clamps. These clamps, CRA-19 and CSA-19, have been rated with $1000 \mathrm{lbs}$ load for new clamps, as shown on pg B-2., Ref 2. Peter Elsabally, Safway Scaffolding (1-206-523-6560), suggested downgrading it (with a .75 factor) for used clamps. The bottom chord at its clamped location needs to be checked for its structural integrity, since this will be the weakest link.

$\mathrm{P}_{\text {clamp }}:=0.75 \cdot 1000 \cdot \mathrm{lbf}$ 
Subject: Evaluation of the Temporary Tent Cover Truss System, AP Primary Vent. System Originator: M. A. Haq Mramf-fal

$$
\begin{aligned}
& \mathrm{P}_{\text {clamp }}=750 \mathrm{lbf} \\
& \mathrm{P}_{\text {clamp }}>\mathrm{F}_{\text {bot.chord }} \\
& \mathrm{d}_{\text {snow }}:=550 \cdot \frac{2.20}{3.281^{3}}
\end{aligned}
$$$$
\mathrm{d}_{\text {snow }}=34.258
$$$$
\mathrm{w}_{\text {firn.snow }}:=\frac{\mathrm{d}_{\text {snow }}}{12} \cdot\left(\frac{3}{8}\right)
$$$$
\mathrm{w}_{\text {firn.snow }}=1.071
$$$$
\mathrm{R}_{\text {truss.snow }}:=\frac{23 \cdot 4 \cdot \mathrm{w}_{\text {firn.snow }}}{2} \cdot \mathrm{lbf}
$$$$
\mathrm{R}_{\text {truss.snow }}=49.246 \mathrm{lbf}
$$$$
F_{\text {bot.chord } 1}:=F_{\text {bot.chord }}+F_{\text {bot.chord }} \cdot \frac{R_{\text {truss.snow }}}{R_{\text {truss }}}
$$$$
\mathrm{F}_{\text {bot.chord } \mathrm{l}}=715.738 \mathrm{lbf}
$$$$
\mathrm{F}_{\text {bot.chord } 1}<\mathrm{P}_{\text {clamp }}
$$

Okay
Okay

Density of firn snow (550 kg per cubic meter, see Attach. D

Note: $1 \mathrm{~kg}=2.20 \mathrm{lbs}, 1$ meter $=3.281 \mathrm{feet}$

Density of snow in lbs per cu ft

Weight of snow (assuming $3 / 8$ " thick) on the truss in psf

Reaction at the truss due to firn snow. Note that the typical truss is $23 \mathrm{ft}$ wide, and spacing of trusses is $4 \mathrm{ft} \mathrm{c} / \mathrm{c}$.

Tension force at the bottom chord of truss by including $3 / 8$ " thick snow

Remove snow on the truss system, if it exceeds $3 / 8^{\prime \prime}$ in thickness

NOTE: If proposed bracings, as shown on the Sketch on pg. E-3 are added, it will add approximately 400 lbs to the truss system. The extra weight will help in overcoming the uplift due to wind, and will make the truss system more conservative. Therefore, there is no need to reanalyze the truss system

\subsection{References}

1.0 ASCE 7-05, Minimum Design Loads for Buildings aand Other Structures, ASCE, Structural Engineering Institute.

2.0 RPP-CALC-42370, Analysis of Existing Scaffolds at AN \& AW Tank Farm Skids, Rev. 0

3.0 TFC-ENG-STD-06, Rev. C-3, Design Loads for Tank Farm Facilities, CH2M Hill Hanford Group, Inc., Richland, Washington.

4.0 AISC, Steel construction, Allowable Stress Design, 9th Edition, American Institue of Steel 
Subject: Evaluation of the Temporary Tent Cover Truss System, AP Primary Vent. System

Originator: M. A. Haq

mantafa

Date: $12 / 22 / 09$

Checker: TC Mackey Date: $12 / 30 / 09$

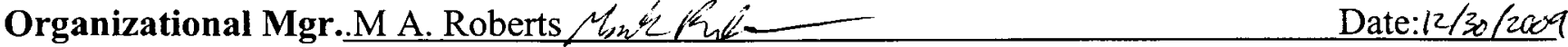

Construction, Chicago, Illnois.

5.0 H-2-90456, Sh 1, Structural, Central Exhaust STA Plans, Sect \& Detail.

$6.0 \quad \mathrm{H}-2-90457$, Structural Central Exh Sta Sect \& Det. 


$$
R P P-C A L C-44193 R O
$$

ATACHMENT A

(Photos of Tent Cover Truss System)

$P G A-1$ 


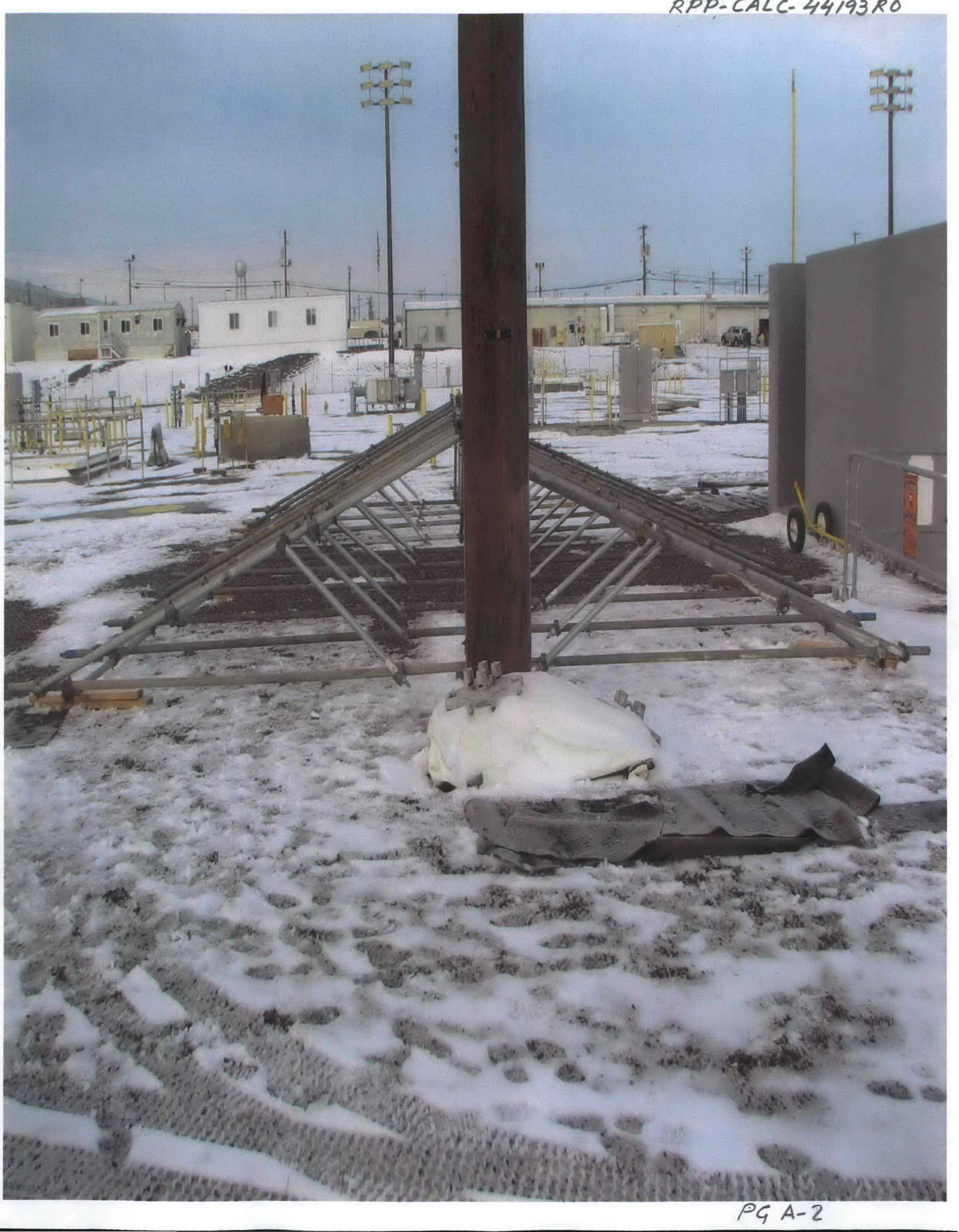




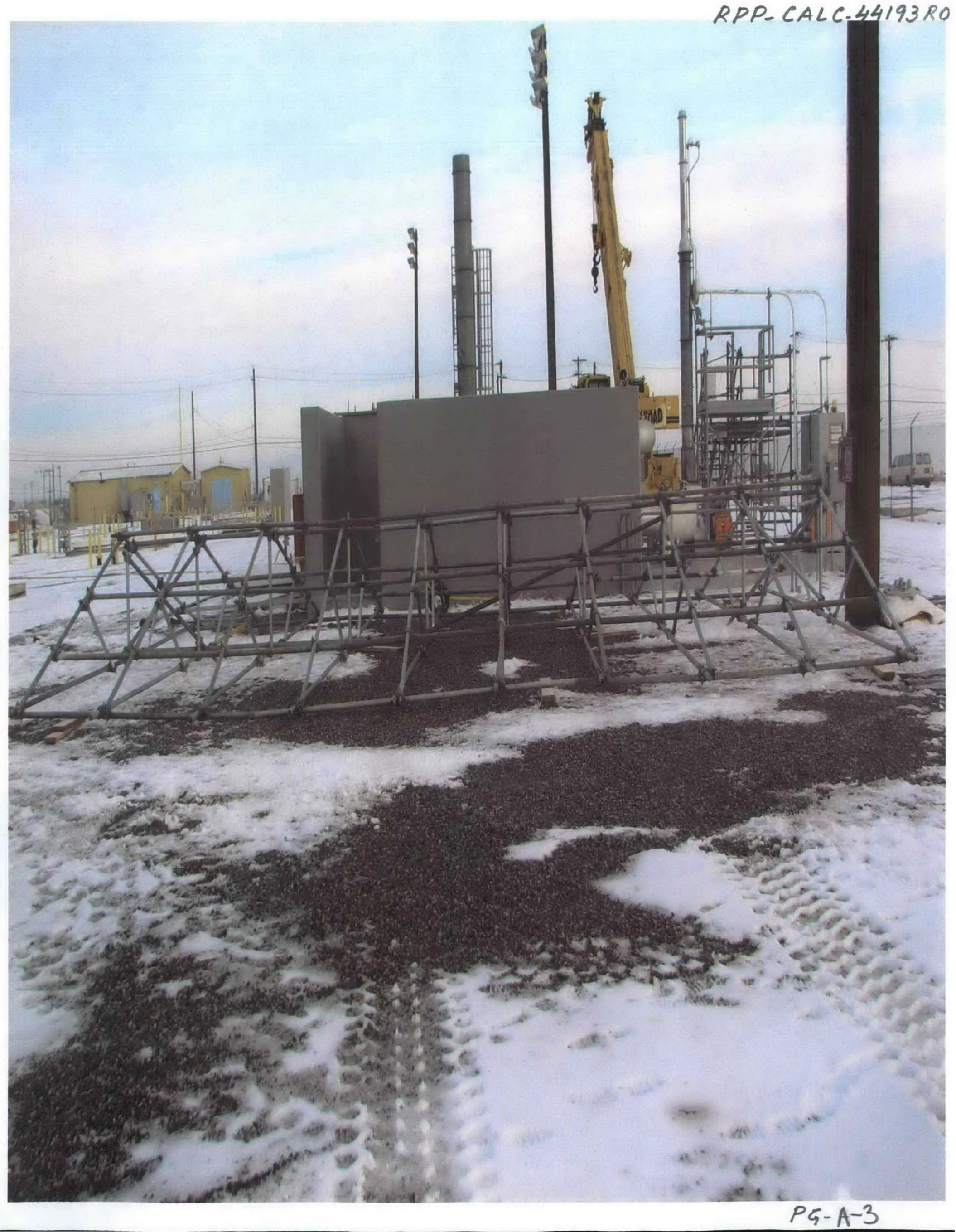




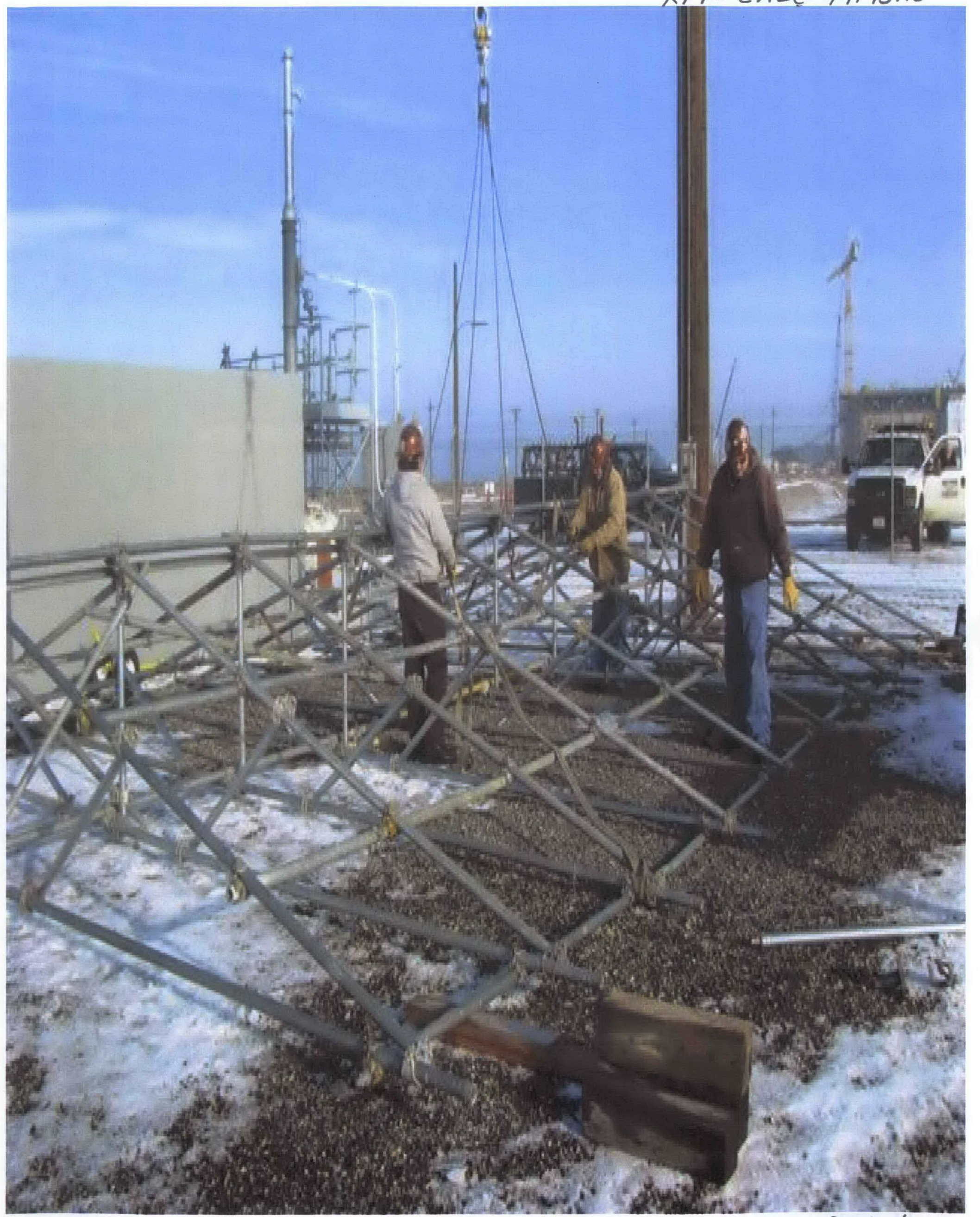


ATACHMENT B

(Sketch for Tent Cover Truss System Support) 
RPP-CALC-44193RO

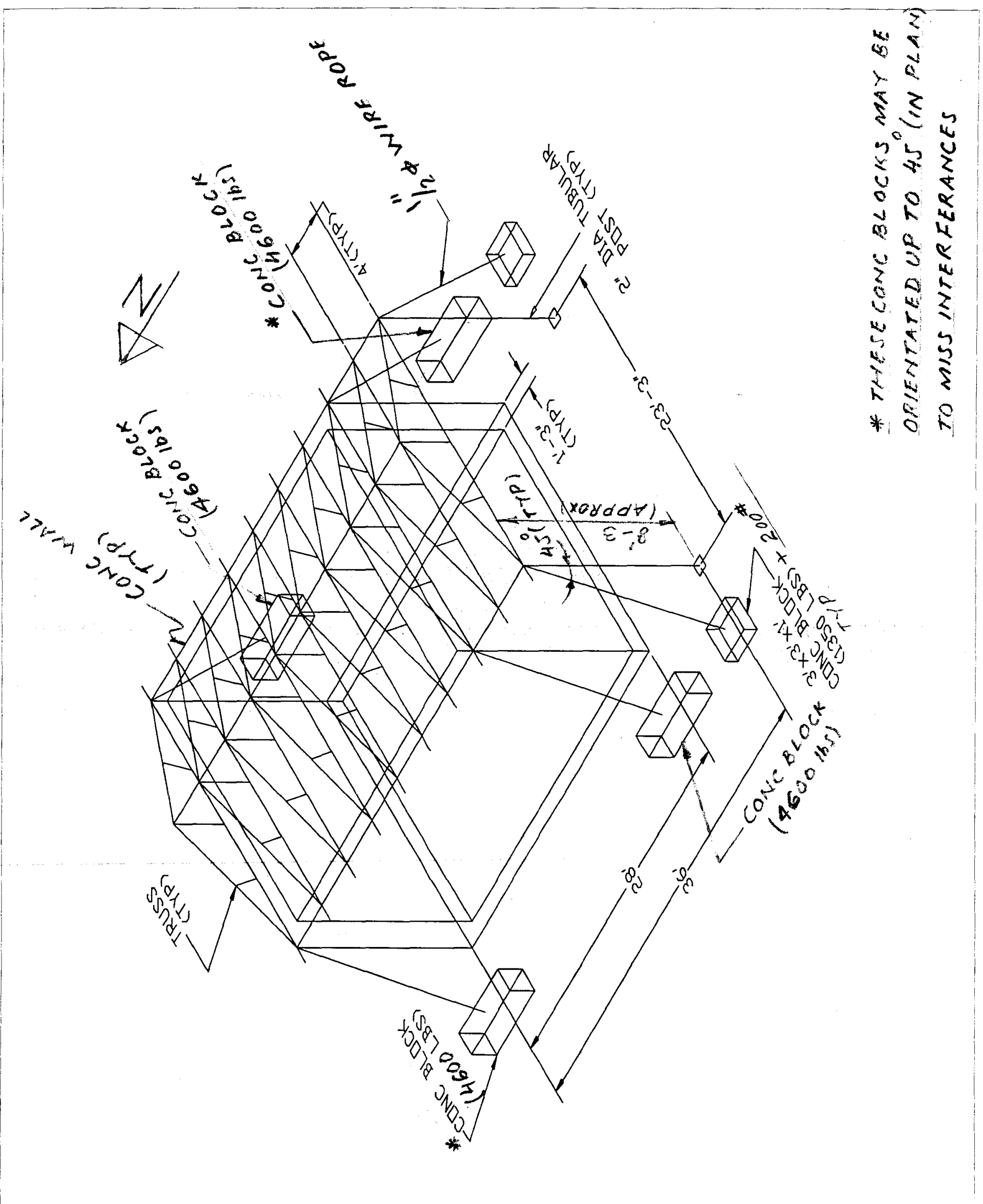




\section{ATACHMENT C}

(Field Sketch for Typical Tent Cover Truss)

$P G, C-1$ 
ATACHMENT D

(Density of Snow Cover Info.)

$P G . D-1$ 


\section{Density of Snow Cover}

\begin{tabular}{lcc}
\multicolumn{1}{c}{ Snow Type } & Density $\left(\mathrm{kg} / \mathrm{m}^{3}\right)$ & $\begin{array}{c}\text { Snow Depth for } \\
\text { One Inch Water }\end{array}$ \\
\hline Wild Snow & 10 to 30 & $98^{\prime \prime}$ to $33^{\prime \prime}$ \\
\hline $\begin{array}{l}\text { Ordinary new snow immediately } \\
\text { after falling in still air }\end{array}$ & 50 to 6.5 & $20^{\prime \prime}$ to $15^{\prime \prime}$ \\
\hline $\begin{array}{l}\text { Setting snow } \\
\text { Average wind-toughened snow }\end{array}$ & 280 & $14^{\prime \prime}$ to $11^{\prime \prime}$ \\
\hline Hard wind slab & 350 & $3.5^{\prime \prime}$ \\
\hline New firn snow & 400 to 550 & $2.8^{\prime \prime}$ \\
\hline Advanced firn snow & 550 to 650 & $2.5^{\prime \prime}$ to $1.8^{\prime \prime}$ \\
\hline Thawing firn snow & 600 to 700 & $1.8^{\prime \prime}$ to $1.5^{\prime \prime}$ \\
\hline
\end{tabular}
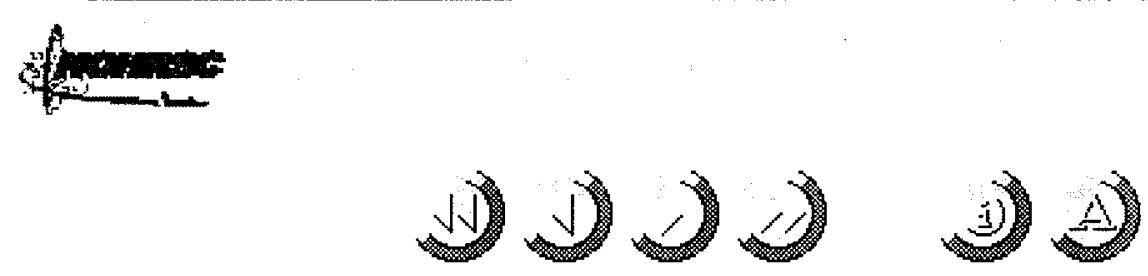

Slide 35 of 107

$$
P G, D-2
$$




\section{ATACHMENT E}

(Alternate Calc. to verify the Strl. Integrity of the Truss System during Hoisting \& Rigging) 


\section{ANALYTICAL CALCULATIONS}

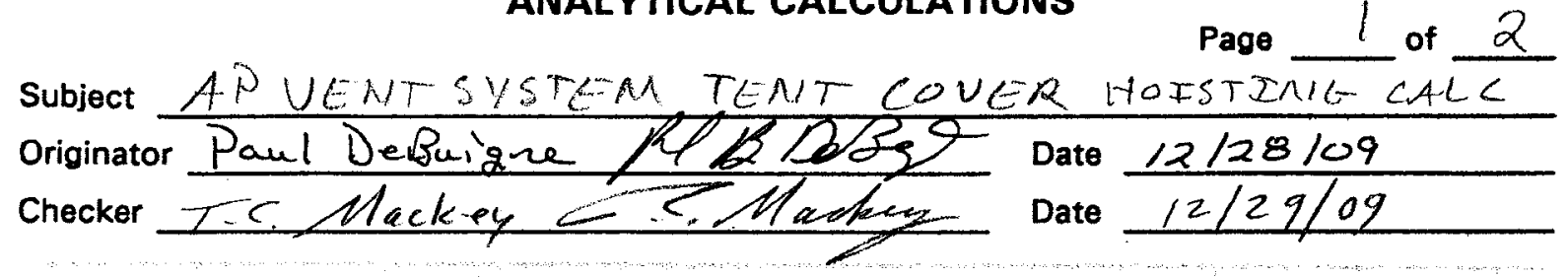

STATEMENT:

THIS IS AN ALTERNATIUE CALCULATION TO UERIFY THE STRUCTURAL TMTEEATTY OF THE FRAMTNG OF THE TRUSS FON HOFSTING ORTALINE

CALCULATION:

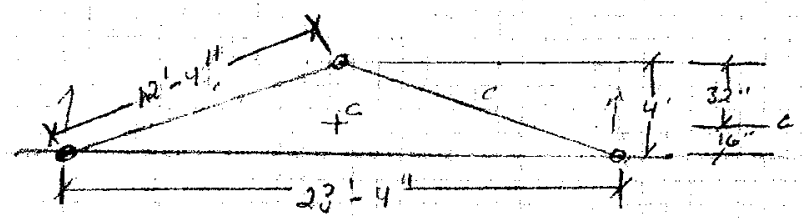

$\rightarrow$ ANALYZE AS A SOLID UNIT:

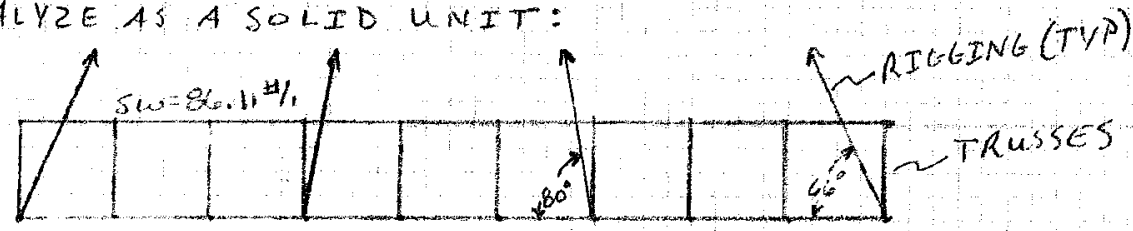

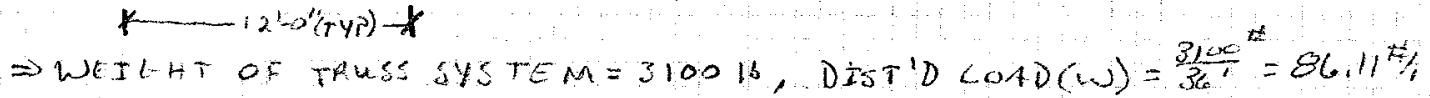

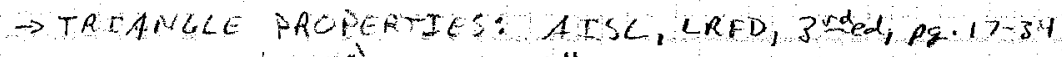

$$
c=\frac{1}{3}\left(48^{n}\right) \quad \quad c=16^{\prime \prime}, C_{1}=32^{\prime \prime}
$$

$I_{\text {Tug }}=0.29 \mathrm{~A}$ " ATube $=0.75 \mathrm{~m}$,

$I=\sum I+A_{12}^{2} \quad I=2\left(0.29+0.75\left(16^{\prime \prime}\right)^{2}\right)+\left(029+0.75622^{\circ}\right) \quad I=408.87 \mathrm{in}^{4}$

$M_{\text {max }}=0.100 \omega L^{2}=1240 H-1=14.88 k-1, L=12-0^{\prime \prime}$

Top chate (compestion):

$$
F_{6=32}=\frac{M c}{I} \quad F_{t r}=1.16 \mathrm{kJI} \times 1.25 \mathrm{IMNAT}=1.45 \mathrm{kgI} \mathrm{VOK}
$$

Bo Ton chol (Teriston):

$$
\begin{aligned}
& F_{S b}=\frac{M_{C}}{I} \quad F_{\Delta_{B}}=0.58 \mathrm{KSI} \times 125 \mathrm{IMPACT}=0.73 \mathrm{ksIVOK} \\
& C=164
\end{aligned}
$$

Chack BOTONC CHORE FOF LOCAL BUCKLINL:

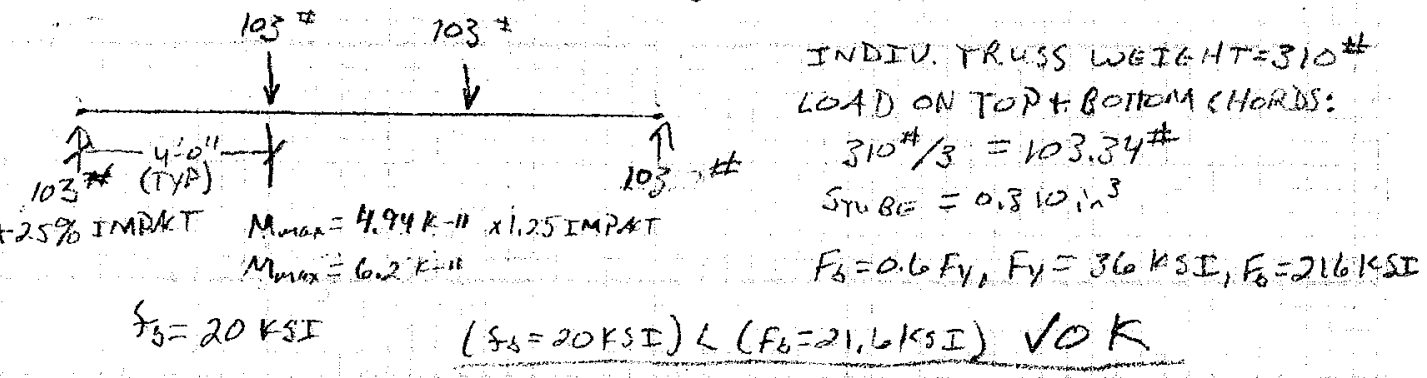




\section{ANALYTICAL CALCULATIONS}

Page 2 of 2

SUbject AP VENT SYSTEN TENT COVER HOISTING CALC

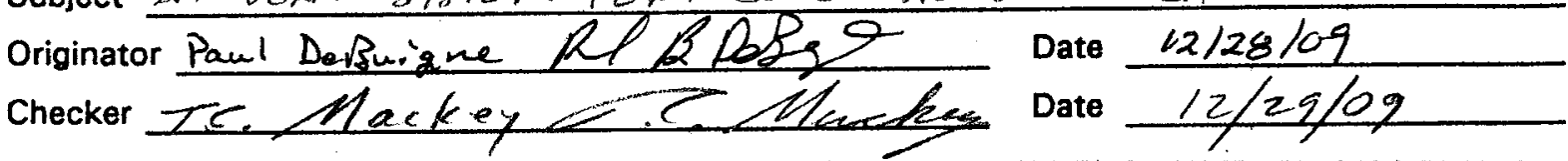

- TRY 4 INTERIAR PICK POINTS WITHENOS BRALLD:
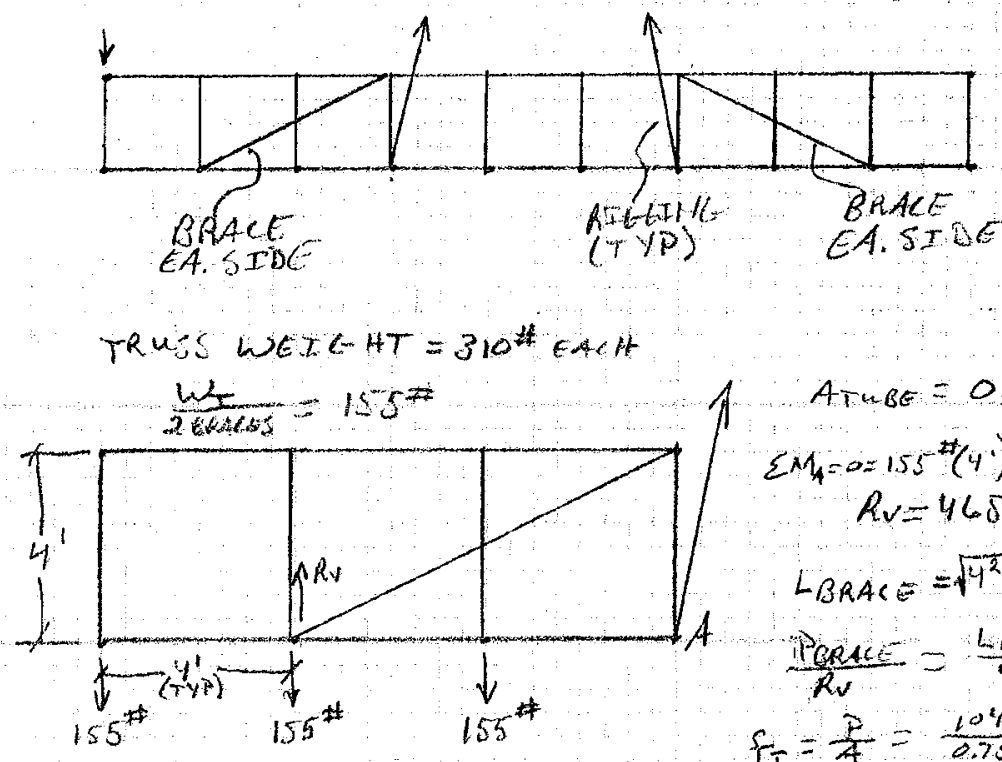

$$
\begin{aligned}
& \text { ATube }=0.75 \mathrm{in}^{2} \\
& \left.\sum M_{4}=0=155^{*}(4)+155^{*}(5)+155^{*}(Q)\right)-R_{U}(8) \\
& R_{v}=46 \delta^{\#} \\
& L_{B R A C E}=\sqrt{4^{2}+8^{2}} \quad L_{B R A C E}=8.944
\end{aligned}
$$

$$
\begin{aligned}
& F_{T}=0.6 F_{y}, F_{y}=36 \mathrm{kI} \quad f_{T}=1.39 \mathrm{ksI} \\
& F_{T}=21.6 \mathrm{kSI} \\
& f_{T}<F_{T} \quad \vee 0 \mathrm{VO}
\end{aligned}
$$

$\rightarrow$ BDTACHSTONAL STRESS OK BV INISPECTION

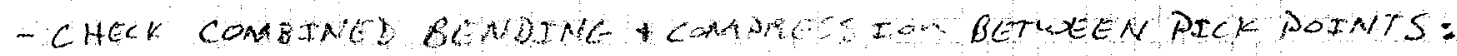
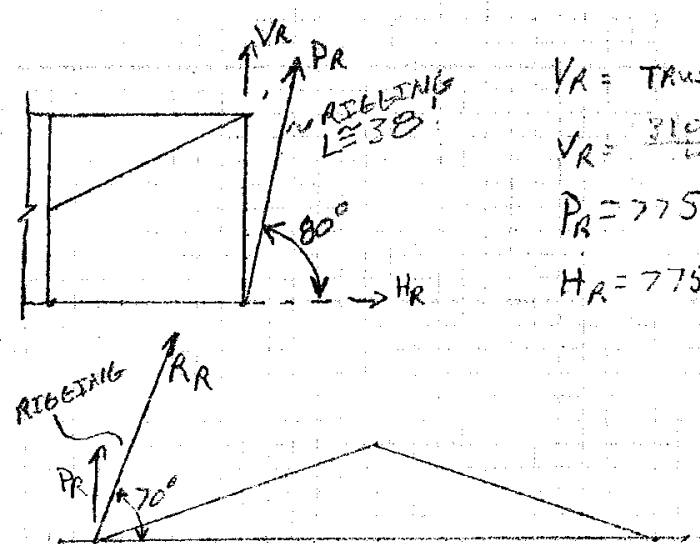

$F_{c}=5.89 k 5 I$

$F_{b}=21.6 \mathrm{ks} L$
$V_{R}=$ TRus SYSTEA WETLAT/4 SLEMGS

$V_{R} \frac{\operatorname{lec} e^{3}}{4} \quad V_{R}^{\prime}=7>5$

$P_{R}=75 \% \cos \left(\beta^{\circ}\right) \quad P_{R}=786.96 \%$

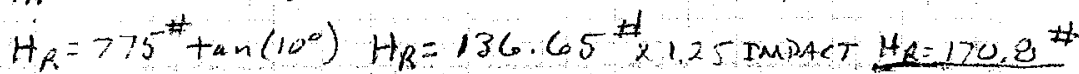

$$
\begin{aligned}
& R_{R}=\frac{P_{R}}{\operatorname{CoS}\left(60^{\circ}\right)} \quad R_{R}=837.5^{24} \times 1,25 \text { IMPACT } \\
& R_{R}=1046.88 \not
\end{aligned}
$$

STR:S: TH BOTTOA STRUTS FROA GGMUTAE

$F_{b}=20 k S I$

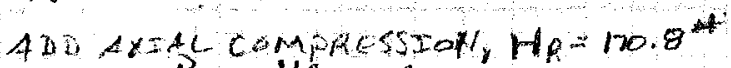

$$
f_{c} \frac{P}{A}=\frac{H A}{A} \quad f_{C}=0.23 \mathrm{ks}
$$

$\frac{f_{c}}{F_{c}}+\frac{f_{3}}{f_{c}}=\frac{0.23}{5.89}+\frac{20}{21.6}=0.965<1.0 \mathrm{VOK}$ 


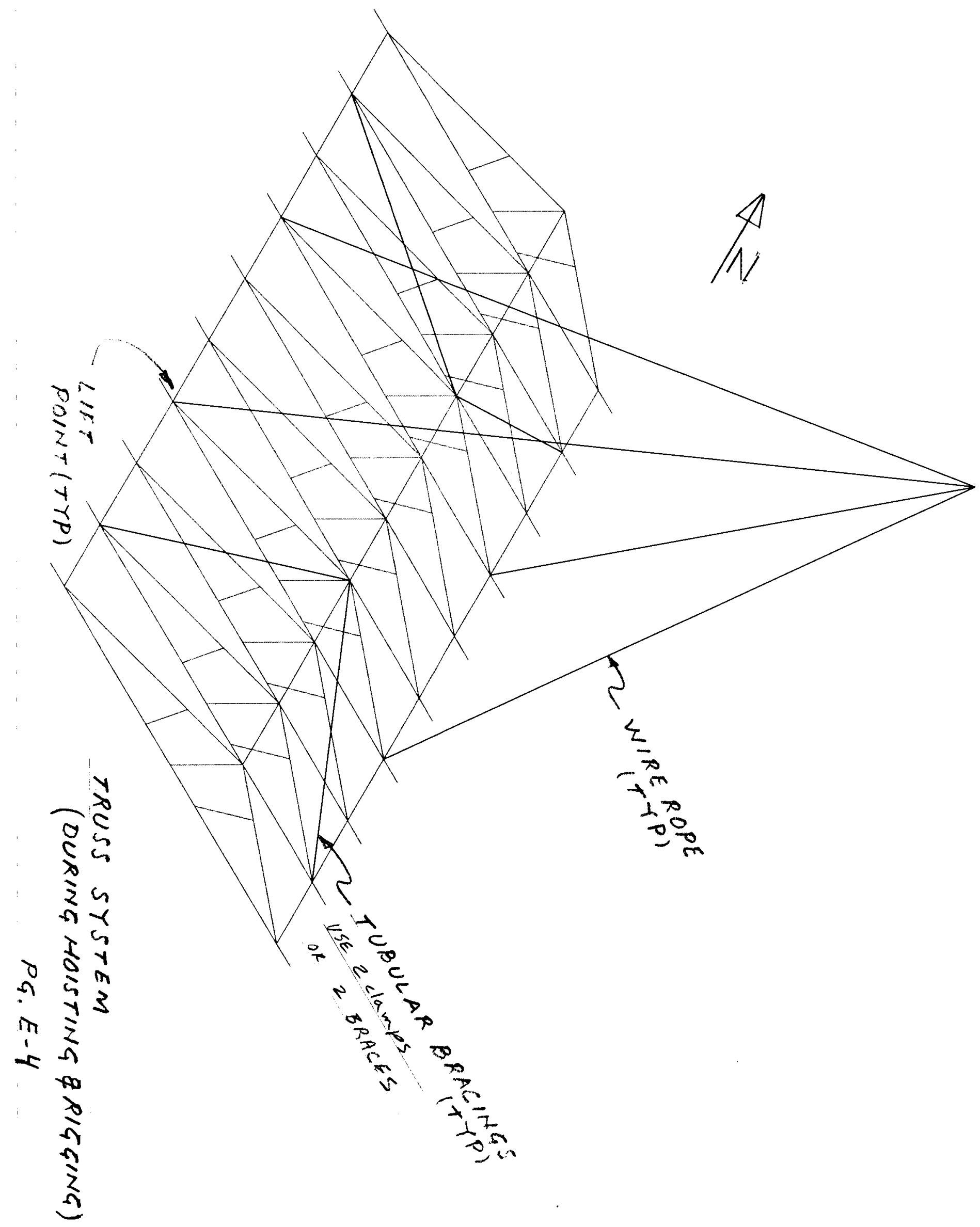

7
0
0
1
1
1
0
0
0
0 